\title{
State-and-Transition Models, Thresholds, and Rangeland Health: A Synthesis of Ecological Concepts and Perspectives
}

\author{
D. D. Briske, ${ }^{1}$ S. D. Fublendorf, ${ }^{2}$ and F. E. Smeins ${ }^{1}$ \\ Authors are ${ }^{1}$ Professors, Department of Rangeland Ecology and Management, Texas A \\ College Station, TX 77843-2126; and ${ }^{2}$ Associate Professor, Department of Plant and Soil Sciences, \\ Oklahoma State University, Stillwater, OK 74078-6028.
}

\begin{abstract}
This article synthesizes the ecological concepts and perspectives underpinning the development and application of stateand-transition models, thresholds, and rangeland health. Introduction of the multiple stable state concept paved the way for the development of these alternative evaluation procedures by hypothesizing that multiple stable plant communities can potentially occupy individual ecological sites. Vegetation evaluation procedures must be able to assess continuous and reversible as well as discontinuous and nonreversible vegetation dynamics because both patterns occur and neither pattern alone provides a complete assessment of vegetation dynamics on all rangelands. Continuous and reversible vegetation dynamics prevail within stable vegetation states, whereas discontinuous and nonreversible dynamics occur when thresholds are surpassed and one stable state replaces another. State-and-transition models can accommodate both categories of vegetation dynamics because they represent vegetation change along several axes, including fire regimes, weather variability, and management prescriptions, in addition to the succession-grazing axis associated with the traditional range model. Ecological thresholds have become a focal point of state-and-transition models because threshold identification is necessary for recognition of the various stable plant communities than can potentially occupy an ecological site. Thresholds are difficult to define and quantify because they represent a complex series of interacting components, rather than discrete boundaries in time and space. Threshold components can be categorized broadly as structural and functional based on compositional and spatial vegetation attributes, and on modification of ecosystem processes, respectively. State-and-transition models and rangeland health procedures have developed in parallel, rather than as components of an integrated framework, because the two procedures primarily rely on structural and functional thresholds, respectively. It may be prudent for rangeland professionals to consider the introduction of these alternative evaluation procedures as the beginning of a long-term developmental process, rather than as an end point marked by the adoption of an alternative set of standardized evaluation procedures.
\end{abstract}

\section{Resumen}

Este artículo sintetiza los conceptos ecológicos y perspectivas en las que se fundamenta el desarrollo y aplicación de los modelos de estado- y- transición, umbrales y salud del pastizal. La introducción del concepto de múltiples estados estables estableció el camino para el desarrollo de estos procedimientos alternativos de evaluación, hipotetizando que múltiples comunidades estables de plantas puede potencialmente ocupar sitios ecológicos individuales. Los procedimientos de evaluación de la vegetación deben ser capaces de evaluar tanto las dinámicas de vegetación continuas y reversibles como las discontinuas y no reversibles, ya que ambos patrones ocurren y ningún patrón solo provee una evaluación completa de las dinámicas de la vegetación en todos los pastizales. Las dinámicas de la vegetación continuas y reversibles prevalecen dentro de los estados estables de la vegetación mientras que las discontinuas y no reversibles ocurren cuando los umbrales son sobrepasados y un estado estable remplaza a otro. Los modelos de estados- y- transición pueden acomodar ambas categorías de dinámicas de la vegetación porque ellos representan el cambio de la vegetación a lo largo de varios ejes, incluyendo regímenes de fuego, variabilidad climática y prescripciones de manejo; además del eje de sucesión-apacentamiento asociado con el modelo tradicional del pastizal. Los umbrales ecológicos han venido a ser un punto central de los modelos de estado- $y$ - transición, porque la identificación de estos umbrales es necesaria para reconocer las diferentes comunidades vegetales estables que potencialmente pueden ocupar un sitio ecológico. Los umbrales son difíciles de definir y cuantificar porque ellos representan una serie compleja de componentes interactuando en lugar de fronteras discretas en tiempo y espacio. Los componentes de los umbrales pueden ser ampliamente categorizados como estructurales y funcionales en base a los atributos de composicionales y espaciales de la vegetación y en la modificación de los procesos de los ecosistemas respectivamente. Los modelos de estados y- transición y los procedimientos de salud del pastizal se han desarrollado paralelamente en lugar de desarrollarse como componentes de una estructura integrada porque los dos procedimientos se basan principalmente en umbrales estructurales y funcionales respectivamente. Pude ser prudente para la profesión de manejo de pastizales considerar la introducción de estas procedimientos alternativos de evaluación como el inicio de un proceso de

The Texas and Oklahoma Agricultural Experiment Stations and USDA-NRI Ecosystem Program (92-37101-7463) funded field research that contributed to this synthesis and the stations provided partial support to the authors during manuscript preparation.

Correspondence: Dr D. D. Briske, Dept of Rangeland Ecology and Management, Texas A\&M University, 2126 TAMU, College Station, TX 77843-2126. Email: dbriske@tamu.edu

Manuscript received 3 September 2003; manuscript accepted 26 September 2004. 
desarrollo a largo plazo, en lugar de un punto final marcado por la adopción de un grupo alternativo de procedimientos estandarizados de evaluación.

Key Words: ecological thresholds, multiple stable states, range condition, rangeland ecology, rangeland evaluation and monitoring

\section{INTRODUCTION}

Knowledge of vegetation dynamics has been the cornerstone of rangeland evaluation from the inception of the rangeland profession. Insight into the various patterns of vegetation dynamics provides an integrated response to prior ecological events and managerial prescriptions, and it presents a practical means to evaluate rangeland resources for various management options (Sampson 1917; Dyksterhuis 1949). Vegetation dynamics also have important implications for ecosystem function because the growth characteristics of individual plant species have pronounced effects on numerous ecosystem processes (Chapin et al. 1997).

During the last 15 years, the rangeland profession has adopted alternative procedures for rangeland evaluation, including stateand-transition models, thresholds, and rangeland health (Westoby et al. 1989; NRC 1994; USDA 1997). The need for alternative evaluation procedures originated from the inability of the traditional method of range condition and trend analysis (range model) to account for the entire spectrum of vegetation dynamics that occurred on rangelands (Dyksterhuis 1949; USDA 1975). The primary limitations of the traditional procedure centered on whether 1) vegetation dynamics are best characterized as continuous and reversible or as discontinuous and nonreversible change, 2) variables such as fire and weather play an equal or greater role than grazing in vegetation dynamics, and 3) vegetation dynamics possess more than one successional pathway and/or stable plant community on individual sites (Fuhlendorf et al. 2001; Briske et al. 2003). Alternative evaluation procedures were developed to address more effectively the limitations associated with the traditional procedure (Westoby et al. 1989; Pyke et al. 2002; Stringham et al. 2003).

The goal of this article is to provide a comprehensive synthesis of the ecological concepts and perspectives underpinning the development and application of alternative procedures for rangeland evaluation. Rapid development of alternative evaluation procedures, often with limited or partial reference to ecological concepts and processes, has contributed to considerable uncertainty and misconception within the rangeland profession. Consequently, several important ecological questions require additional attention. To what extent are state-and-transition models supported by ecological theory? What is the ecological basis for application of the threshold concept? What ecological information is required to link state-and-transition models with rangeland health? We argue that closer inspection of the ecological concepts and perspectives underpinning vegetation dynamics will enhance the development of ecologically sound and managerially effective procedures for rangeland evaluation.

A clear understanding of the ecological concepts and processes supporting the development and application of alternative evaluation procedures has important implications for the science of rangeland ecology and natural resource conservation and management on rangelands throughout the world. This synthesis contains three sections developed to 1) provide a brief history of relevant events, 2) describe the current status of vegetation evaluation procedures, and 3) present a perspective for future development of rangeland evaluation procedures.

\section{A BRIEF HISTORY}

Several interacting events in ecological theory, the rangeland profession, and the US political arena set the stage for the development of alternative procedures for rangeland evaluation. These events are discussed in chronological order to demonstrate how they contributed to the current development of rangeland evaluation procedures.

\section{Traditional Procedure}

Sampson (1917) initially associated the evaluation of rangeland vegetation with ecological concepts following the development of successional theory by Clements (1916). Sampson (1919) stated, "the one reliable, indeed the only direct, scientific way of detecting pasture depletion in its early stages is by observing the succession of the conspicuous vegetation, that is, the replacement of one set or type of plants by another." However, a quantitative procedure for the evaluation of rangeland vegetation dynamics was not developed for another 30 years when Dyksterhuis (1949) published his classic article outlining rangeland condition and trend analysis. This procedure was applied to rangelands throughout the world during the last half of the 20th century. However, the procedure encountered considerable criticism even during the early stages of development and implementation (Joyce 1993).

The range model represented vegetation change along a single axis defined by the successional theory of Clements (1916). It was assumed that grazing intensity could counteract secondary succession to alter the species composition of plant communities (Fig. 1). Range condition for a given ecological (range) site was defined by the current species composition of a community along this succession-grazing axis relative to the composition of a fire climax community that was presumed to dominate the North American landscape at the time of European settlement (Dyksterhuis 1949; Smith 1988; Westoby et al. 1989). Range trend described the relative change in range condition on specific sites through time. Range condition ratings were used to draw inferences for both production goals and ecological assessments (Joyce 1993).

The inability of the range model to account for the encroachment of woody vegetation and persistent exotic invaders provided a major limitation and a strong incentive for the development of an alternative evaluation procedure (Laycock 1989; Smith 1989). The initial decision to use the grassland/savanna fire climax community (e.g., pre-European, Native American), as opposed to the climatic climax community (e.g., shrubland or woodland), as the single end point of succession was a primary source of this limitation on many 
rangelands. This decision was based on a land use bias that focused on the importance of livestock grazing and the widespread occurrence of fire climax communities at the time of European settlement (Smith 1988). Nevertheless, this decision greatly reduced the utility of the range model when fire regimes were altered or suppressed, and the climatic climax was expressed to a greater extent than the grassland/savanna fire climax communities. The conversion of grassland to woodland communities was described as a "type conversion," but this designation was never incorporated into the range model and these communities were classified as poor range condition (USDA 1975).

\section{An Alternative Procedure}

Criticism of the range model focused on the inability of a linear, single-axis model founded on Clementsian succession to describe effectively the entire spectrum of vegetation dynamics that occur on rangelands (Laycock 1989, 1991; Smith 1989). Westoby et al. (1989) identified several ecological processes, including episodic periods of drought or favorable precipitation, altered fire regimes, and severe soil erosion, that could produce nonlinear vegetation dynamics. Recognition of these processes provided a strong incentive for an alternative or substantially modified evaluation procedure that would accommodate a broader spectrum of vegetation dynamics than the range model.

The introduction of state-and-transition models by Westoby and others (1989) provided an alternative procedure that was not limited to a single axis of vegetation change or a single climax plant community. This alternative procedure attracted a great deal of attention because it resolved many of the criticisms of the range model by expressing more effectively the multivariate nature of vegetation dynamics. The National Research Council (NRC 1994) and SRM Task Group (1995) also endorsed the development of alternative evaluation procedures in response to concerns of the US Congress that emphasized the inability of traditional vegetation evaluation procedures to provide a comprehensive assessment of the ecological condition of the Nation's rangelands (Laycock 2003; Smith 2003). This indicates that the development of alternative evaluation procedures was partially motivated by a political agenda (NRC 1994), but the need to modify evaluation procedures had a strong ecological basis as well.

\section{Underpinning Ecological Theory}

The development and adoption of alternative procedures for rangeland evaluation represents a progressive maturation of rangeland ecology based on a broader interpretation of ecological theory. The multiple stable state concept (Holling 1973; May 1977) and the nonequilibrium paradigm (Wiens 1984; Ellis and Swift 1988) paved the way for the development of state-andtransition models, the threshold concept, and rangeland health procedures. Adoption of the multiple stable state concept forced the development of an alternative procedure for vegetation evaluation because the range model could not represent more than one stable plant community on an individual site (e.g., climax theory emphasizing the grassland/savanna state). Thresholds were introduced to define boundaries in space and time among the multiple stable communities that could potentially occupy

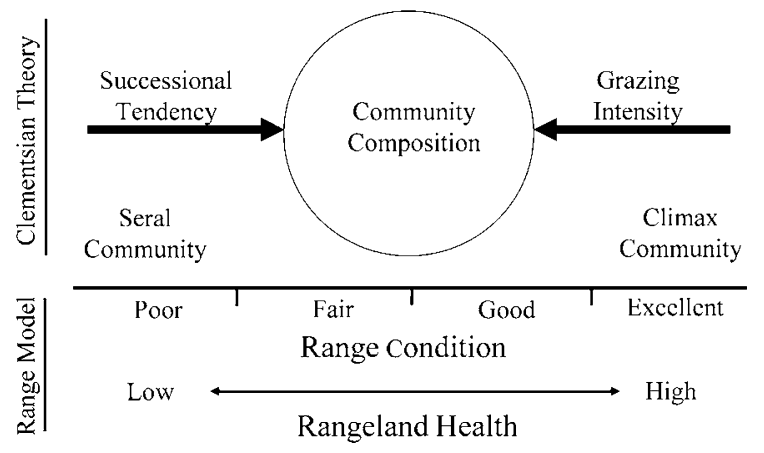

Figure 1. The range model describes vegetation dynamics along a single axis defined by succession and grazing intensity. Grazing can slow, stop, or reverse secondary succession to produce communities with various species combinations that are assigned to specific range condition classes. These conditions classes were often equated with rangeland health. Modified from Westoby et al. (1989) with permission of the Society for Range Management.

a site. An alternative procedure was required to evaluate rangeland health because the presumed correlation between various condition classes and ecosystem function was reduced by the recognition of multiple stable states and successional pathways on individual sites (e.g., Ellison 1949; Dyksterhuis 1949; Pendleton 1989). This is illustrated by the shift in emphasis from community composition to soil- and hydrologybased indicators in the current rangeland health procedures (Pyke et al. 2002).

It is now clear that vegetation evaluation procedures must be able to measure and interpret both continuous reversible and discontinuous nonreversible vegetation dynamics because both patterns occur and neither pattern alone represents the entire spectrum of vegetation dynamics on all rangelands ( $\mathrm{Wu}$ and Loucks 1995; Watson et al. 1996; Illius and O'Connor 1999). Continuous and reversible vegetation dynamics prevail within stable vegetation states, whereas discontinuous and nonreversible dynamics occur when thresholds are surpassed and one stable state replaces another. Both patterns of vegetation dynamics have important implications for rangeland ecology and management, and their occurrence supports the conclusion that a shift from the equilibrium to the nonequilibrium paradigm would not benefit rangeland ecology (Briske et al. 2003). A paradigm shift would only redirect our emphasis of vegetation dynamics from one end of the equilibrium-nonequilibrium continuum to the other. This could contribute to the perception that vegetation dynamics are exclusively discontinuous and irreversible, just as the range model overemphasized continuous and reversible vegetation dynamics. Rangeland ecology will best be served by the integration of both the range and state-andtransition models and their respective ecological paradigms.

\section{CURRENT STATUS OF PROCEDURES}

The ecological concepts and processes underlying the development and application of alternative evaluation procedures are explored in this section. The ecological basis for these alternative procedures is often overlooked and occasionally misinterpreted, and important ecological questions have yet to be 


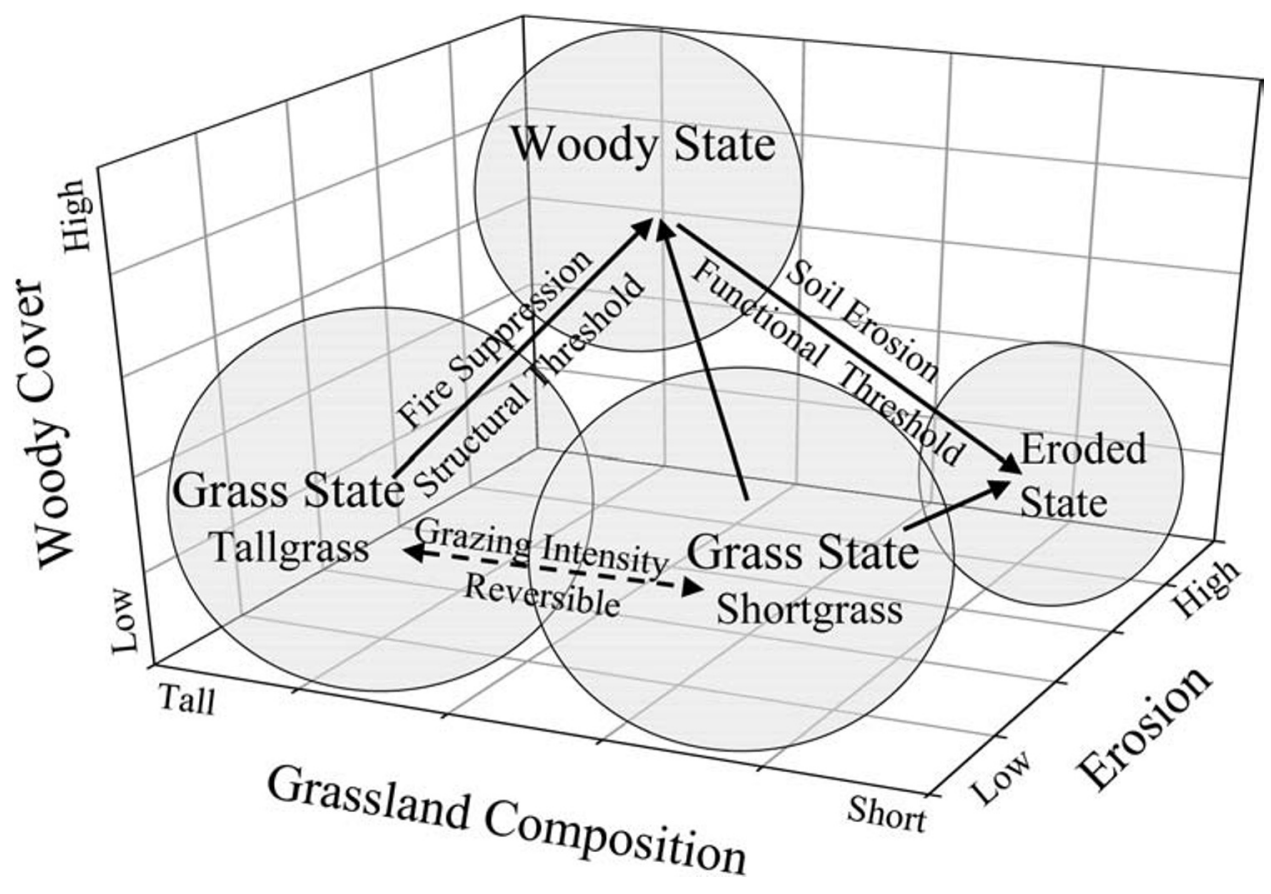

Figure 2. Conceptual model of the multiple stable state concept illustrating selected stable states that may potentially occur on an individual site. Unique states are depicted as spheres within a three-dimensional volume that represents the potential of the site to support alternative states through time. The range model is founded on the single horizontal axis defined by succession and grazing intensity, which determines species composition in a grassland state (e.g., tall versus shortgrass structure). State-and-transition models accommodate greater complexity by describing vegetation dynamics in response to multiple drivers and by representing transitions to alternative stable states on individual ecological sites. Structural thresholds are defined by changes in species and growth form composition and spatial vegetation distribution, whereas functional thresholds signify changes in various ecosystem processes. Dashed and solid arrows depict reversible and nonreversible transitions, respectively.

fully explored. These ecological concepts require additional emphasis to support the continued development of effective evaluation procedures for rangeland application.

\section{State-and-Transition Models}

Description and Development. State-and-transition models were presented as a framework to accommodate a broader spectrum of vegetation dynamics on the basis of managerial, rather than ecological, criteria (Westoby et al. 1989). These models were initially designed for application on rangelands characterized by discontinuous and nonreversible vegetation dynamics, but they were not intended to replace the range model or suggest that continuous and reversible vegetation change did not occur. The original interpretation indicated that this framework was to be constructed on the basis of 1) potential alternative vegetation states on a site, 2) potential transitions between vegetation states, and 3 ) recognition of opportunities to achieve favorable transitions and hazards to avoid unfavorable transitions between vegetation states (Westoby et al. 1989). Even though the expressed goal of state-and-transition models was to provide a framework for vegetation management, considerable ecological knowledge and experience is required to define the ecosystem properties associated with these categories of information (Bestelmeyer et al. 2004).

The original state-and-transition framework did not specify the use of an ecological reference point (Westoby et al. 1989). However, the historic plant community, as defined in the traditional range model, has been adopted as an ecological reference within state-and-transition models developed by the Natural Resource Conservations Service (NRCS) in the United States (USDA 1997). The desired plant community (SRM Task Group 1995 ) represents an alternative reference point for use in these models that is based on management as well as ecological criteria.

State-and-transition models can account for a broader spectrum of vegetation dynamics than the range model because they can represent vegetation change along several axes, including fire regimes, soil erosion, weather variability, and management prescriptions, in addition to the secondary succession-grazing axis associated with the range model (Fig. 2). The successiongrazing axis can track vegetation dynamics within a grassland state, but it cannot accommodate the existence of vegetation transitions to alternative stable states. For example, fire suppression has contributed to vegetation transitions (e.g., fire threshold) from a grassland to a woodland state on many rangelands located in both mesic and semiarid environments (Archer 1994; Fuhlendorf et al. 2001; Briggs et al. 2002). In contrast, weather variation is assumed to contribute to vegetation dynamics within states, rather than between states, for all but the most severe events (but see Ellis and Swift 1988; Bestelmeyer et al. 2004).

The interpretation presented in Figure 2 illustrates that stateand-transition models can incorporate reversible and directional vegetation change as described by the range model (Westoby et al. 1989; Bestelymer et al. 2003; Briske et al. 2003). This interpretation is also evidenced by the development of stateand-transition models that closely parallel the traditional range model in grassland regions or where the only substantial modification is the addition of a stable woody plant community (e.g., climatic climax). Recognition that state-and-transition models can incorporate the range model serves to unify further the development of vegetation evaluation procedures for rangeland application.

The variables of fire, weather, and grazing may interact to produce unique patterns of vegetation dynamics. The livestock 


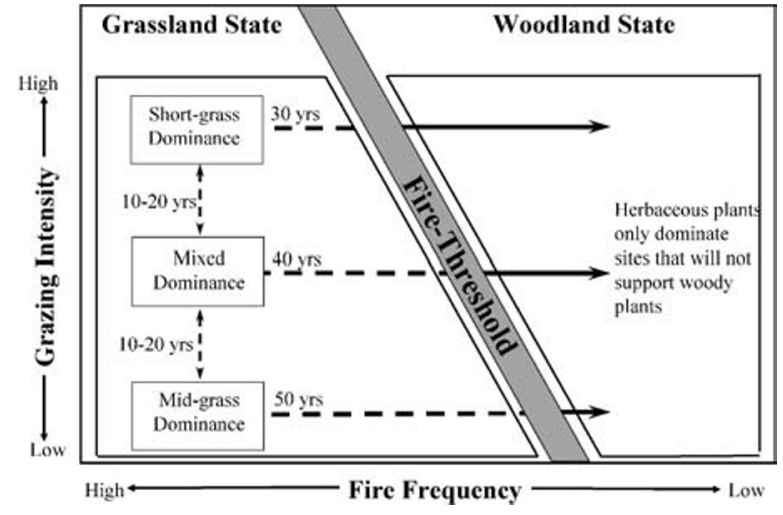

Figure 3. Illustration of a fire threshold separating grassland and woodland stable states. Transitions among the various grassland communities (dashed arrows) are reversible with grazing management. Grassland composition can influence the rate at which a threshold (solid arrows) is crossed in the absence of fire, but it cannot prevent the threshold from being crossed. Reprinted from Fuhlendorf and Smeins (1997) with permission of Opulus Press.

grazing-fire interaction is the most widely recognized and understood interaction contributing to woody plant encroachment (Fig. 3). Livestock grazing interacts with fire to reduce fuel loads, reduce herbaceous competition with woody seedlings, and enhance woody plant seed dispersal (Archer and Smeins 1991; Archer 1994). Consequently, grazing can influence the rate at which the fire threshold is surpassed (Fuhlendorf et al. 1996; Fuhlendorf and Smeins 1997), but it does not directly define the threshold in the absence of fire (Brown and Archer 1989, 1999). The removal of grazing would not be expected to reverse the process of woodland conversion without reinstatement of the fire regime (West and Yorks 2002). In some cases, thresholds may not even be reversed when the prior disturbance regime is reinstated based on the occurrence of reinforcing feedbacks within ecosystems (Smith 1988; Friedel 1991; Scheffer et al. 2001).

It is important to recognize that the greatest utility of stateand-transition models originates from the expression of vegetation dynamics along multiple axes, rather than from the development of new ecological information or processes describing the function of rangeland ecosystems. These models provide a framework to catalog information for a greater number of plant communities and vegetation transitions than does the range model, but they do not inherently provide greater insight into the ecological processes associated with this broader spectrum of vegetation dynamics (Rodriguez Iglesias and Kothmann 1997; Archer and Stokes 2000). Their major advantage is that they accommodate the occurrence of the multiple stable state concept (Holling 1973; May 1977), whereas the range model does not. Development of effective ecological site descriptions is a critical feature of state-and-transition models because the descriptions provide the interpretive information associated with these models. These descriptions explicitly define the various vegetation states, transitions, and thresholds that may occur on a site in response to natural and management events (Pyke et al. 2002; Stringham et al. 2003).

Threshold Concept. Thresholds have become a focal point in the development and application of state-and-transition models

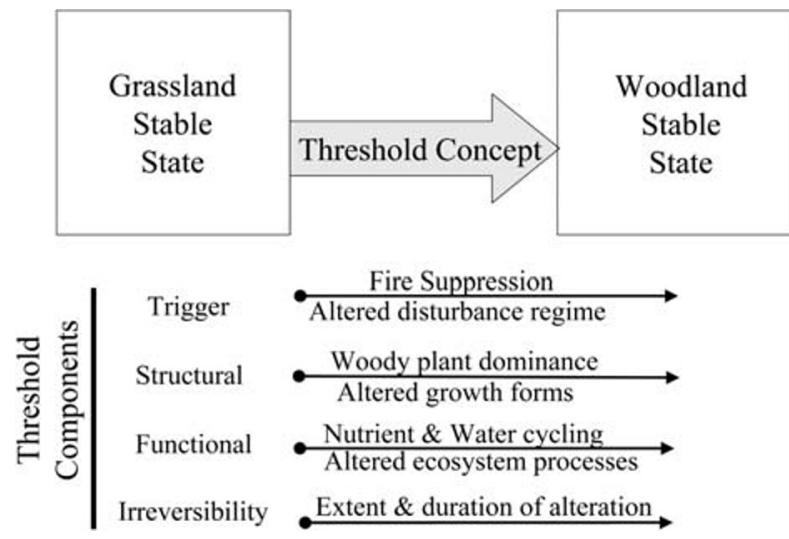

Figure 4. Ecological thresholds consist of several components that increase their complexity and contribute to the occurrence of a continuum of thresholds on rangelands. A specific event may trigger the occurrence of a threshold that effects both structural and functional modifications during transitions over various time scales. Threshold reversibility is dependent on the extent and duration of structural and functional ecosystem modifications.

(e.g., Stringham et al. 2003) even though they were not specifically referenced in the original framework (Westoby et al. 1989). It is generally accepted that successional processes, ecological disturbances, and management prescriptions, either alone or in combination, may cause one stable community to cross a threshold to an alternative stable community on the same site. We argue that the initial application of thresholds based on nonreversible transitions in a management time frame (Friedel 1991; Laycock 1991) requires further development for effective interpretation and management of rangeland ecosystems. Thresholds often define management, rather than ecological thresholds, because the time frame for vegetation change is based primarily on management alternatives bounded by human longevity, rather than by changes in ecological processes. More recently, Stringham et al. (2003) have incorporated ecological processes in the threshold concept by indicating that, "one or more of the primary ecological processes has been irreversibly changed and must be actively restored before return to the previous state is possible" (p. 109). This represents a valuable and necessary advance in the threshold concept that is founded on ecological resilience (Peterson et al. 1998). However, considerable work is required to formulate a functional interpretation of the ecological processes associated with thresholds for rangeland application.

Ecological thresholds describe a complex set of potentially interacting components, rather than discrete boundaries in time and space (Figs. 3 and 4). A specific disturbance or event may trigger the occurrence of a threshold that effects both structural and functional modifications during ecosystem transitions of various time scales. The potential for threshold reversibility is dependent on the extent and duration of ecosystem modifications, especially those altering nutrient and water cycles and energy flow pathways. Ecosystem modification often imposes a series of feedback mechanisms that maintains or reinforces the altered state and limits reversal to the previous stable state (Archer et al. 2001; Scheffer et al. 2001; van de Koppel et al. 2002). Consequently, thresholds are difficult to identify and 


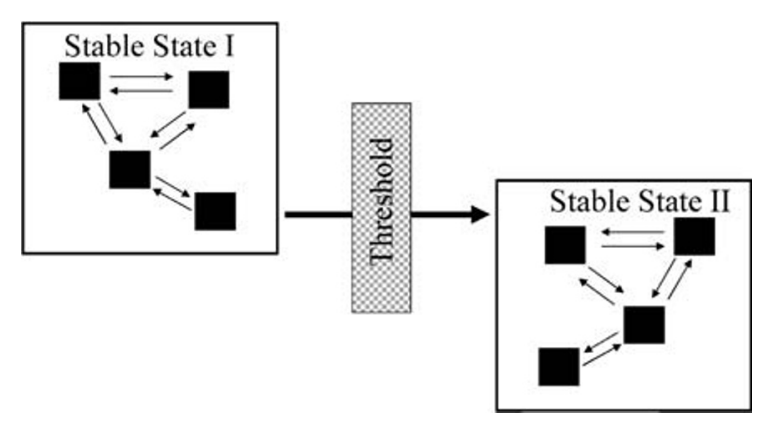

Figure 5. Illustration of the potential pathways of vegetation dynamics that may occur within and between stable plant communities. Transitions among communities (squares within states) within a stable state are reversible, but those between stable states are not. Both reversible and nonreversible vegetation dynamics must be evaluated for accurate ecological assessments and management applications. Modified from Stringham et al. (2003) with permission of the Society for Range Management.

interpret because they represent a continuum from those that are readily reversed to those that are difficult (or even impossible) to reverse by management intervention.

Excessive emphasis on thresholds may be misinterpreted to suggest that management is of little consequence and might thereby reduce incentives for adaptive vegetation management (Stafford Smith 1996; Fernandez-Gimenez and Allen-Diaz 1999). The most effective application of state-and-transition models is to assess the relative benefits and potential risks of various management prescriptions and ecological conditions on subsequent vegetation dynamics (Bestelmeyer et al. 2003, 2004). This application is based on recognition that vegetation dynamics within stable communities influences the development of impending thresholds (Westoby et al. 1989; Watson et al. 1996; Stringham et al. 2003) (Fig. 5). Effective vegetation management can prevent plant communities from crossing a threshold by maintaining or enhancing the resilience or recovery potential of the community (Scheffer et al. 2001). Alternatively, effective management can accelerate the rate at which undesirable plant communities may cross thresholds to preferred communities by restoring damaged components and processes (Whisenant 1999; Suding et al. 2004).

Ecological thresholds can be categorized into two general groups; their distinction has important ecological and managerial implications (Fig. 4). The first group involves structural or compositional thresholds that are based on changes in community composition, plant growth form, and the occurrence of invasive species (e.g., Friedel 1991; Laycock 1991; Scheffer et al. 2001; Stringham et al. 2003). The spatial distribution of vegetation also represents an important structural component because it influences the potential for erosion and resource retention on ecological sites (Schlesinger et al. 1990; Ludwig et al. 2000). The second group involves functional thresholds that are defined by positive or negative changes in various ecological processes (e.g., soil and hydrologic properties, nutrient cycling and productivity) (Archer et al. 2001, van de Koppel et al. 2002). Structural and functional thresholds are interrelated to varying degrees, but functional thresholds are anticipated to lag behind structural thresholds based on the time required to modify ecosystem processes.
Assessments of functional thresholds are primarily derived from indicators of structural attributes because ecosystem function is difficult to evaluate and quantify (Havstad and Herrick 2003).

State-and-transition models primarily rely on structural thresholds, which are appropriate for vegetation management, but they provide only indirect evidence of ecosystem function. In contrast, rangeland health primarily emphasizes functional thresholds based on the use of ecological indicators that reflect changes in ecosystem processes (Pyke et al. 2002). The reliance of these two rangeland evaluation procedures on distinct categories of thresholds has determined that they develop in parallel, rather than as components of an integrated framework.

The specific vegetation attributes used to evaluate vegetation dynamics merit greater consideration because they can substantially alter the interpretation of those dynamics. For example, total basal area of perennial grasses is affected primarily by interannual precipitation, perennial grass density is significantly affected by both grazing and weather variability, and mean basal area per plant is much more responsive to grazing than to interannual precipitation over the long term (Fuhlendorf et al. 2001). These contrasting responses to grazing and weather indicate that measurement of one attribute (e.g., total basal area) may suggest stable community composition, whereas another may indicate a significant compositional change through time. Fernandez-Gimenez and Allen-Diaz (1999) concluded that the evaluation of a broad spectrum of vegetation attributes would provide a more thorough interpretation of vegetation dynamics than evaluation of an individual or small subset of attributes.

\section{Rangeland Health}

The concept of rangeland health was introduced in the mid-20th century and it was generally accepted that rangeland health varied directly with community condition class or successional stage as defined by the range model (Dyksterhuis 1949; Ellison 1949) (Fig. 1). Recognition of the occurrence of multiple stable states and successional pathways minimized the significance of this perceived correlation. Rangeland health is currently defined as, "the degree to which the integrity of the soil, vegetation, water and air as well as the ecological processes of the ecosystem are balanced and sustained" (USDA 1997; Pyke et al. 2002 p. 585). Ecological integrity describes, "the maintenance of the functional attributes characteristic of a locale, including normal variability" (Pyke et al. 2002 p. 585). In North America, current rangeland health evaluations are based on 17 indicators organized into three categories of ecosystem function: 1) soil and site stability, 2) hydrologic function, and 3) integrity of the biotic community. A similar set of indicators has been incorporated in a conceptual framework describing the relative ability of vegetation patches within a landscape to capture and conserve resources and maintain ecosystem function (Ludwig and Tongway 2000; Ludwig et al. 2000). Many of these indicators had been developed for application with the traditional range model. The NRC (1994) and SRM Task Group (1995) both endorsed the development of alternative procedures to evaluate rangeland health, and several federal land management agencies have developed and evaluated rangeland health procedures during the last decade (Pyke et al. 2002). 
The current rangeland health procedure has not been recommended for trend evaluation through time, but only as a point in time assessment (Pyke et al. 2002). This interpretation is based on 1) low repeatability on specific sites among years, and 2) the absence of quantitative techniques that potentially could provide greater precision in assessing ecosystem properties. However, even the development of quantitative techniques to measure important ecosystem properties (e.g., soil organic carbon) will still require considerable effort to define reference points for acceptable ecosystem function and to account for variation among rangeland regions. The qualitative nature of the current procedure has contributed to the cautionary note that it should only be used by individuals with experience and knowledge of a specific rangeland ecosystem (NRC 1994; Pyke et al. 2002).

Identification and quantification of functional thresholds, within the multiple stable state framework, is a fundamental problem confronting rangeland health evaluation. The site conservation threshold represents an attempt to define a single functional threshold based on the type, amount, and pattern of vegetation required to prevent accelerated soil erosion on individual sites (SRM Task Group 1995). However, even a single functional threshold has proven difficult to define and quantify for ecological sites, because the relationship between structural and functional thresholds is difficult to evaluate with current procedures (Havstad and Herrick 2003).

\section{PERSPECTIVES FOR CONTINUED ADVANCEMENT}

An important theme of this synthesis is to encourage the development and application of alternative rangeland evaluation procedures with an "eyes wide open" perspective. Rapid and complete adoption of the state-and-transition framework with limited scientific inquiry is reminiscent of the adoption of the range model. Both the underlying ecological concepts and managerial application of the state-and-transition framework need to be continually re-evaluated and refined to ensure development of sound and effective procedures for rangeland application. It may be prudent for rangeland professionals to consider the introduction of these alternative evaluation procedures as the beginning of a long-term developmental process, rather than as an end point marked by the adoption of an alternative set of standardized evaluation procedures.

\section{State-and-Transition Models}

State-and-transition models can accommodate a broad spectrum of vegetation dynamics, but they will need to be linked directly with ecological theory if rangeland ecology is to continue to underpin rangeland management (Provenza 1991; Joyce 1993; Bestelmeyer et al. 2003). The quantitative description of individual states represents a minimum requirement for scientific evaluation so that statistical distinctions can be made among various states. Greater knowledge of the characteristics and rates of occurrence of both structural and functional thresholds, in response to both natural and management events, will be essential for continued development of effective state-and-transition models. A theoretical foundation would not have to encumber the managerial flexibility of these models and it would enable the rangeland profession to substantiate more effectively the validity of the information obtained through the use of these models. Managerial expediency should not take precedence over ecological validity in the development of alternative evaluation procedures, but rather the two endeavors should advance in tandem (e.g., Provenza 1991).

\section{Thresholds}

Two categories of information are required for more effective development and application of thresholds. The first is the practical information required to define and anticipate the occurrence of thresholds on a variety of rangelands. Greater insight into the rate at which thresholds will be approached and surpassed in response to natural and human-induced events, both alone and in combination, is necessary to enhance their application (e.g., Fuhlendorf and Smeins 1997; Archer and Stokes 2000; Bestelmeyer et al. 2003). It may be valuable to assign a chronological reference to various categories of thresholds when possible (e.g., Valone et al. 2002; Heisler et al. 2003; Bestelmeyer et al. 2004).

The second category of information is greater insight into the effect of structural thresholds on ecological function. Inferences regarding functional thresholds that are derived from the occurrence of structural thresholds should be made with caution (e.g., Stringham et al. 2003). The assumption that structural thresholds frequently correspond with functional thresholds parallels the assumption of ecosystem retrogression with decreasing condition classes within the range model. When a structural threshold has been surpassed, it suggests that a site has become dominated by a community with a distinct species composition, but this does not necessarily imply that ecosystem function has been negatively altered (Archer et al. 2001). For example, net annual primary production and soil carbon and nitrogen pools have been demonstrated to increase substantially in mesic environments (Archer et al. 2001; Norris et al. 2001; Hibbard et al. 2003), and net aboveground production remained similar in semiarid environments (Huenneke et al. 2002), following grassland conversion to woodland and shrubland, respectively. The unique characteristics of structural and functional thresholds are most evident when multiple stable states involve functionally similar species that minimize the effect of altered vegetation structure on ecosystem processes (Chase 2003).

\section{Rangeland Health}

Adoption of the multiple stable state and threshold concepts has eliminated the perception that rangeland health can be directly inferred from community composition and requires that health be redefined and assessed with a broader set of ecosystem attributes. The development of quantitative techniques to measure important ecosystem properties (e.g., soil organic carbon) will represent a critical advance for the assessment of rangeland health, but they may not be readily available or cost-effective for other than research applications at small scales (Pyke et al. 2002). Consequently, functional inferences derived from structural attributes will continue to represent the major approach to rangeland health assessments. Current procedures must be refined and novel procedures identified that will strengthen the linkage between structural and functional thresholds. Plant functional types (Walker 1995; Díaz et al. 2002) and spatial vegetation distribution (Schlesinger et al. 1990; Ludwig et al. 2000) represent examples of potential linkages. 


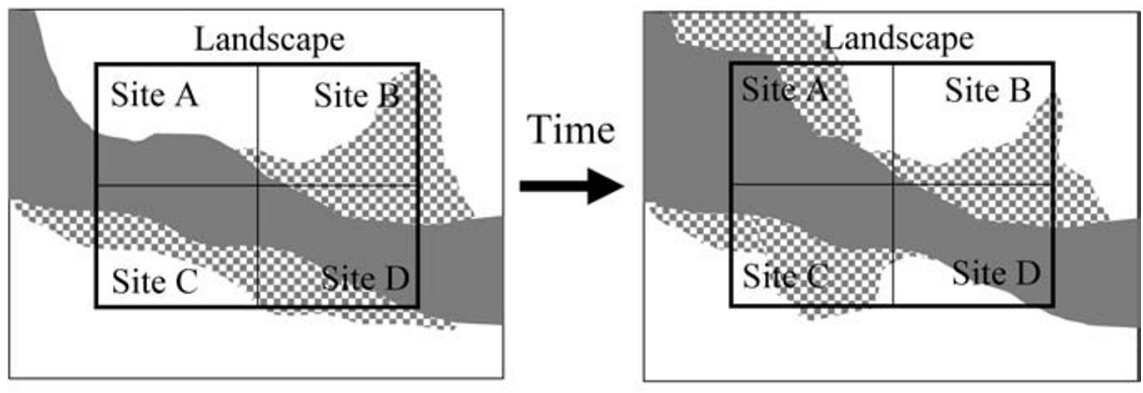

Grassland Low Density Woodland

High Density Woodland

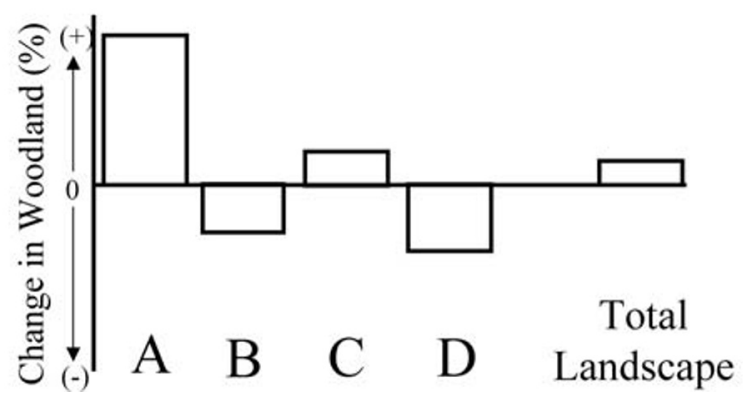

Figure 6. Schematic contrasting the interpretation of vegetation dynamics on individual sites within a landscape. Unique and opposing vegetation changes on individual sites may offset one another to minimize vegetation change within the landscape. Woodland increased on site A, but decreased on sites $B$ and $D$ to minimize vegetation change on the landscape. Landscape and regional assessments of vegetation dynamics will require procedures that can integrate vegetation dynamics among multiple sites and spatial scales.

Many rangeland ecosystems have long surpassed one or more thresholds in response to land use practices, modified disturbance regimes, and altered site characteristics. These ecosystems may best be managed to restore ecosystem function, with reduced emphasis on the final species composition of the site (Stringham et al. 2003). This restoration approach will require an understanding of how various thresholds constrain ecosystem function, and a prediction of how these thresholds may respond to restoration practices (Whisenant 1999; Suding et al. 2004).

\section{Spatial Scale}

A critical challenge confronting development of alternative procedures for effective rangeland evaluation is the incorporation of spatial scale (Briske et al. 2003; West 2003). Rangeland evaluation often focuses on individual sites, which minimizes the confounding effects of landscape heterogeneity (i.e., variation among sites), but it also limits interpretation of vegetation dynamics within landscapes (Fuhlendorf and Smeins 1996, 1998, 1999; Stafford Smith 1996). Unique and disproportionate changes in the species composition of individual sites may produce various patterns of vegetation change within landscapes (Fig. 6) (Ryerson and Parmenter 2001; Landsberg et al. 2002). The extensive use of individual ecological sites as management units may have shaped our perception of vegetation dynamics by overemphasizing the rate and magnitude of vegetation change compared with that which occurs on larger land areas (Briske et al. 2003). This interpretation supports the conclusions of Pyke and others (2002) that site-specific data should not be combined into state- or national-level assessments without incorporating some quantitative data, stratifying the landscape into hierarchical units (e.g., ecological sites and major land resource areas), and applying a statistically valid sampling methodology.

The importance of spatial scale for the interpretation of vegetation dynamics is supported by both ecological theory (DeAngelis and Waterhouse 1987) and long-term vegetation records (Fuhlendorf et al. 2001), but scale has yet to be incorporated within a conceptual framework. The investigation of scale-related issues needs to be established as a priority goal by both research institutions and land management agencies. The ability to interpret vegetation dynamics within a framework of spatial scale is probably the only valid approach for complying with the recommendations of the NRC (1994) and SRM Task Group (1995) to provide a comprehensive ecological assessment of the Nation's rangelands. Rangeland assessment at landscape and regional scales will require the development of alternative procedures that measure a unique set of variables capable of integrating information among multiple sites (e.g., Ludwig et al. 2000; van de Koppel et al. 2002; Havstad and Herrick 2003).

\section{ACKNOWLEDGMENTS}

Participants in various NRCS rangeland ecology short courses provided D. D. B. and F. E. S. with valuable context and encouragement for the development of this synthesis. We wish to thank D. M. Engle, J. A. Ludwig, 3 anonymous reviewers, and the associate editor, M. McClaran, for numerous insightful contributions that markedly improved the final version of this manuscript.

\section{LITERATURE CITED}

ARCHER, S. 1994. Woody plant encroachment into southwestern grasslands and savannas: Rates, patterns and proximate causes. In: M. Vavra, W. Laycock, 
and R. Pieper [eds.]. Ecological implications of livestock herbivory in the West. Denver, CO: Society for Range Management. p 13-68.

ArCheR, S., T. W. Boutton, and K. A. HibBard. 2001. Trees in grasslands: biogeochemical consequences of woody plant expansion. In: E.-D. Schulze, S. P. Harrison, M. Heimann, E. A. Holland, J. Lloyd, I. C. Prentice, and D. Schimel [eds.]. Global biogeochemical cycles in the climate system. San Diego, CA: Academic Press. p 115-137.

Archer, S., and F. E. Smeins. 1991. Ecosystem-level processes. In: R. K. Heitschmidt and J. W. Stuth [eds.]. Grazing management: an ecological perspective. Portland, OR: Timber Press. p 109-139.

ArCher, S., and C. Stokes. 2000. Stress, disturbance and change in rangeland ecosystems. In: 0. Arnalds and S. Archer [eds.]. Rangeland desertification. Boston, MA: Kluwer Academic Publishers. p 17-38.

Bestelmeyer, B. T., J. R. Brown, K. M. Havstad, R. Alexander, G. Chavez, and J. E. HerRick. 2003. Development and use of state-and-transition models for rangelands. Journal of Range Management 56:114-126.

Bestelmeyer, B. T., J. E. Herrick, J. R. Brown, D. A. Trujillo, and K. M. Havstad. 2004. Land management in the American southwest: a state-and-transition approach to ecosystem complexity. Environmental Management 34:38-51.

Briggs, J. M., G. A. Hoch, ANd L. C. Johnson. 2002. Assessing the rate, mechanisms, and consequences of the conversion of tallgrass prairie to Juniperus virginiana forest. Ecosystems 5:578-586.

Briske, D. D., S. D. Fuhlendorf, and F. E. Smeins. 2003. Vegetation dynamics on rangelands: a critique of the current paradigms. Journal of Applied Ecology 40:601-614.

Brown, J. R., AND S. ARcher. 1989. Woody plant invasion of grasslands: establishment of honey mesquite (Prosopis glandulosa var. glandulosa) on sites differing in herbaceous biomass and grazing history. Oecologia 80:19-26.

Brown, J. R., AND S. ARCHER. 1999. Shrub invasion of grasslands: recruitment is continuous and not regulated by herbaceous density or biomass. Ecology 80:2385-2396.

Chapin, F. S., B. H. Walker, R. J. Hobbs, D. U. Hooper, J. H. Lawton, O. E. Sala, and D. Tilman. 1997. Biotic control over the functioning of ecosystems. Science 277:500-504.

CHASE, J. M. 2003. Community assembly: when should history matter? Oecologia 136:489-498.

Clements, F. E. 1916. Plant succession: an analysis of the development of vegetation. Washington, DC: Carnegie Institution of Washington. Publication 242. $512 \mathrm{p}$.

DeAngelis, D. L., and J. C. Waterhouse. 1987. Equilibrium and nonequilibrium concepts in ecological models. Ecological Monographs 57:1-21.

DíAz, S., D. D. BRISKE, AND S. McInTYRE. 2002. Range management and plant functional types. In: A. C. Grice and K. C. Hodgkinson [eds.]. Global rangelands: Progress and prospects. Wallingford, UK: CAB International. p 81-100.

Dyksterhuis, E. J. 1949. Condition and management of rangeland based on quantitative ecology. Journal of Range Management 2:104-105.

Ellis, J. E., AND D. M. Swift. 1988. Stability of African pastoral ecosystems: alternate paradigms and implications for development. Journal of Range Management 41:450-459.

ELLISON, L. 1949. The ecological basis for judging condition and trend on mountain rangeland. Journal of Forestry 47:787-795.

Fernandez-Gimenez, M. E., and B. Allen-Diaz. 1999. Testing a non-equilibrium model of rangeland vegetation dynamics in Mongolia. Journal of Applied Ecology 36:871-885.

FrIEDEL, M. H. 1991. Range condition assessment and the concept of thresholds: a viewpoint. Journal of Range Management 44:422-426.

Funlendorf, S. D., D. D. BRiske, And F. E. SmeIns. 2001. Herbaceous vegetation change in variable rangeland environments: the relative contribution of grazing and climatic variability. Applied Vegetation Science 4:177-188.

Funlendorf, S. D., AND F. E. Smeins. 1996. Spatial scale influence on long-term temporal patterns of a semi-arid grassland. Landscape Ecology 11:107-113.

Funlendorf, S. D., And F. E. Smeins. 1997. Long-term vegetation dynamics mediated by herbivores, weather and fire in a Juniperus-Quercus savanna. Journal of Vegetation Science 8:819-828.

Funlendorf, S. D., And F. E. Smeins. 1998. The influence of soil depth on plant species response to grazing within a semi-arid savanna. Plant Ecology 138:89-96.

Funlendorf, S. D., And F. E. Smeins. 1999. Scaling effects of grazing in a semi-arid savanna. Journal of Vegetation Science 10:731-738.

Funlendorf, S. D., F. E. Smeins, and W. E. Grant. 1996. Simulation of a fire-sensitive ecological threshold: a case study of Ashe juniper on the Edwards Plateau of Texas, USA. Ecological Modelling 90:245-255.

Havstad, K. M., and J. E. HerRick. 2003. Long-term ecological monitoring. Arid Land Research and Management 17:389-400.

HeIsLer, J. L., J. M. Briggs, And A. K. Knapp. 2003. Long-term patterns of shrub expansion in a C4-dominated grassland: fire frequency and the dynamics of shrub cover and abundance. American Journal of Botany 90:423-428.

Hibbard, K. A., D. S. Schimel, S. Archer, D. S. Ojima, and W. Parton. 2003. Grassland to woodland transitions: integrating changes in landscape structure and biogeochemistry. Ecological Applications 13:911-926.

Holuıng, C. S. 1973. Resilience and stability of ecological systems. Annual Review of Ecology and Systematics 4:1-23.

Huenneke, L. F., J. P. Anderson, M. Remmenga, and W. H. Schlesinger. 2002. Desertification alters patterns of aboveground net primary production in Chihuahuan ecosystems. Global Change Biology 8:247-264.

Illius, A. W., AND T. G. O'Connor. 1999. On the relevance of non-equilibrium concepts to arid and semi-arid grazing systems. Ecological Applications 9:798-813.

Joyce, L. A. 1993. The life cycle of the range condition concept. Journal of Range Management 46:132-138.

Landsberg, J., C. D. James, J. Maconochie, A. 0. Nicholls, J. Stol, and R. Tynan. 2002. Scale-related effects of grazing on native plant communities in an arid rangeland region of South Australia. Journal of Applied Ecology 39:427-444.

LAYcock, W. A. 1989. Secondary succession and range condition criteria: introduction to the problem. In: W. K. Lauenroth and W. A. Laycock [eds.]. Secondary succession and the evaluation of rangeland condition. Boulder, CO: Westview Press. p 1-15.

Laycock, W. A. 1991. Stable states and thresholds of range condition on North American rangelands: a viewpoint. Journal of Range Management 44:427-433.

LAYcock, W. A. 2003. Lessons from the past: have we learned from our mistakes? Arid Land Research and Management 17:359-367.

LudWIG, J. A., AND D. J. Tongway. 2000. Viewing rangelands as landscape systems. In: 0. Arnalds and S. Archer [eds.]. Rangeland desertification. Boston, MA: Kluwer Academic Publishers. p 39-52.

LudWig, J. A., J. A., Wiens, and D. J. Tongway. 2000. A scaling rule for landscape patches and how it applies to conserving soil resources in savannas. Ecosystems 3:84-97.

MaY, R. M. 1977. Thresholds and breakpoints in ecosystems with a multiplicity of stable states. Nature 269:471-477.

NorRis, M. D., J. M. Blair, L. C. Johnson, and R. B. McKane. 2001. Assessing changes in biomass, productivity, and $\mathrm{C}$ and $\mathrm{N}$ stores following Juniperus virginiana forest expansion into tallgrass prairie. Canadian Journal of Forest Research 31:1940-1946.

NRC (National Research Council) 1994. Rangeland health: New methods to classify, inventory, and monitor rangelands. Washington DC: National Academy Press, $180 \mathrm{p}$.

Pendleton, D. T. 1989. Range condition as used in the Soil Conservation Service. In: W. K. Lauenroth and W. A. Laycock [eds.]. Secondary succession and the evaluation of rangeland condition. Boulder, CO: Westview Press. p 17-34.

Peterson, G., C. R. Allen, and C. S. Holling. 1998. Ecological resilience, biodiversity, and scale. Ecosystems 1:6-18.

Provenza, F. D. 1991. Viewpoint: range science and range management are complementary but distinct endeavors. Journal of Range Management 44:181-183.

Pyke, D. A., J. E. Herrick, P. Shaver, and M. Pellant. 2002. Rangeland health attributes and indicators for qualitative assessment. Journal of Range Management 55:584-597.

Rodriguez Iglesias, R. M., and M. M. Kothmann. 1997. Structure and causes of vegetation change in state and transition model applications. Journal of Range Management 50:399-408. 
Ryerson, D. E., and R. R. Parmenter. 2001. Vegetation change following removal of keystone herbivores from desert grasslands in New Mexico. Journal of Vegetation Science 12:167-180.

Sampson, A. W. 1917. Succession as a factor in range management. Journal of Forestry 15:593-596.

SAmpson, A. W. 1919. Plant succession in relation to range management. Washington, DC: United States Department of Agriculture Bulletin 791.

Scheffer, M., S. Carpenter, J. A. Foley, C. Folke, and B. Walker. 2001. Catastrophic shifts in ecosystems. Nature 413:591-596.

Schlesinger, W. H., J. F. Reynolds, G. L. Cunningham, L. F. Huenneke, W. M. Jarrell, R. A. VIRGIINIA, AND W. G. Whitford. 1990. Biological feedbacks in global desertification. Science 247:1043-1084.

Sмiтh, E. L. 1988. Successional concepts in relation to range condition assessment. In: P. T. Tueller [ed.]. Vegetation science applications for rangeland analysis and management. Boston, MA: Kluwer Academic Publishers. $p$ 113-133.

Smith, E. L. 1989. Range condition and secondary succession: a critique. In: W. K Lauenroth and W. A. Laycock [eds.]. Secondary succession and the evaluation of rangeland condition. Boulder, C0: Westview Press. p 103-141.

Sмiтt, E. L. 2003. The struggle for a uniform monitoring system. Arid Land Research and Management 17:347-358.

SRM Task Group (Society for Range Management Task Group on Unity in Concepts and Terminology Committee, Society for Range Management). 1995. New concepts for assessment of rangeland condition. Journal of Range Management 48: 271-282.

StafFoRd Smith, M. 1996. Management of rangelands: paradigms at their limits. In: J. Hodgson and A.W. Illius [eds.]. The ecology and management of grazing systems. Wallingford, UK: CAB International. p 325-357.

Stringham, T. K., W. C. Krueger, and P. L. Shaver. 2003. State and transition modeling: an ecological process approach. Journal of Range Management $56: 106-113$.

Suding, K. N., K. L. Gross, and G. R. Houseman. 2004. Alternative states and positive feedbacks in restoration ecology. Trends in Ecology and Evolution 19:46-53.
USDA, NRCS. 1997. National range and pasture handbook. Washington, DC: United States Department of Agriculture, Natural Resource Conservation Service, Grazing Lands Technology Institute. 190-vi-NRPH.

USDA, SCS. 1975. National range handbook. Washington, DC: United States Department of Agriculture, Soil Conservation Service.

Valone, T. J., M. Meyer, J. H. Brown, and R. M. Chew. 2002. Timescale of perennial grass recovery in desertified arid grasslands following livestock removal. Conservation Biology 16:995-1002.

van de Koppel, J., M. Rietkerk, F. van Langevelde, L. Kumar, C. A. Klausmeier, J. M. Fryxell, J. W. Hearne, J. van Andel, N. de Ridder, A. Skidmore, L. Stroosnijder, AND H. H. T. Prins. 2002. Spatial heterogeneity and irreversible vegetation change in semiarid grazing systems. American Naturalist 159:209-218.

WaLKER, B. 1995. Conserving biological diversity through ecosystem resilience. Conservation Biology 9:747-752.

Watson, I. W., D. G. BuRnside, and A. McR. Holm. 1996. Event-driven or continuous; which is the better model for managers? Australian Rangeland Journal 18:351-369.

WeSt, N. E. 2003. Theoretical underpinnings of rangeland monitoring. Arid Land Research and Management 17:333-346.

West, N. E., and T. P. YoRKS. 2002. Vegetation responses following wildfire on grazed and ungrazed sagebrush semi-desert. Journal of Range Management $55: 171-181$

Westoby, M., B. H. Walker, And I. Noy-Meir. 1989. Opportunistic management for rangelands not at equilibrium. Journal of Range Management 42:266-274.

Whisenant, S. G. 1999. Repairing damaged wildlands: A process-oriented, landscape-scale approach. New York, NY: Cambridge University Press. $312 \mathrm{p}$

WIENS, J. A. 1984. On understanding a nonequilibrium world: myth and reality in community patterns and processes. In: D. R. Strong, D. Simberloff, L. Abele, and A. B. Thistle [eds.]. Ecological communities: Conceptual issues and the evidence. Princeton, NJ: Princeton University Press. p 439-458.

Wu, J., AND 0. L. Loucks. 1995. From balance of nature to hierarchical patch dynamics: a paradigm shift in ecology. Quarterly Review of Biology 70: 439-466. 